\title{
Subject Focus in West African Languages
}

International Conference on Information Structure

6-8 June, 2006, University of Potsdam

Ines Fiedler, Katharina Hartmann, Brigitte Reineke, Anne Schwarz, Malte Zimmermann

$\{$ k.hartmann, sfb632.b1\}@rz.hu-berlin.de

\section{Introduction}

Joint venture of:

Project B1 (Fiedler, Reineke, Schwarz): Focus in Gur and Kwa languages

Project B2 (Hartmann, Zimmermann): Focusing in Chadic languages

Topic of the talk:

Discussion of focus marking in three West African language groups: Gur, Kwa, (West) Chadic. Note: Most data were elicited by ourselves, for some Chadic languages, data from the literature were added.

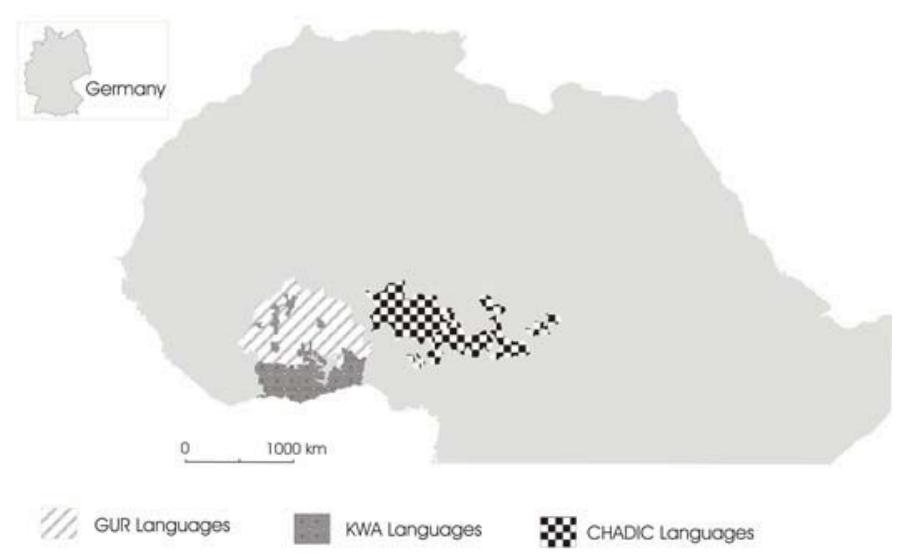

i. The examined tone languages exhibit wide variation in their grammatical means of focus marking (syntactic, morphological, prosodic) $\rightarrow$ section 1

ii. There is a clear-cut asymmetry in the realization of subject focus (SF) and nonsubject focus (NSF)

$\rightarrow$ section 2

iii. Discussion of the special status of focused subjects

$\rightarrow$ section 3

General remarks on language groups discussed

i. Areal distribution:

Kwa: Nigeria, Benin, Togo, Ghana, Ivory Coast

Gur: $\quad$ Nigeria, Benin, Togo, Ghana, Ivory Coast, Burkina Faso, Mali

Chadic: Northern Nigeria, Niger, Cameroon, Chad

ii. Our presentation is based on a language sample comprising the following languages Kwa: Aja, Akan, Efutu, Ewe, Fon, Foodo, Lelemi

Gur: Buli, Byali, Dagbani, Ditammari, Gurene, Konkomba, Konni, Nateni, Yom Chadic:Hausa, Tangale, Bole, Guruntum, Ngizim, Bade, Duwai

iii. General grammatical properties:

- tone languages, tone has lexical and grammatical function

- basic structure SVO with full NPs

- no morphological case marking 


\section{Linguistic means of expressing term focus}

This part illustrates the grammatical means used to express focus in the languages discussed. We will demonstrate this using instances of non-subject term focus (NSF).

Terminological remarks

Focus: Information-structural category, i.e. that information that is most important / salient in a given discourse situation (cf. Jackendoff 1972, Dik 1997).

Focus marking: Linguistic realization of focus in form of special grammatical means.

Preliminary remarks

Although we will concentrate on marked focus in the following, it is important to note that NSF need not be marked at all in many languages in the sample: Fon, Aja, Ewe, Foodo, Lelemi, Akan, Efutu (all Kwa), Hausa, Bole (Chadic) can employ the canonical word order (SVO) (in-situ focus), and need not make use of special prosodic patterns or special morphological markers either.

(1) Fon (Kwa, Gbe)

Q: What did the woman eat?

A: é dù àyìkún.

3 sg eat beans

'She ate BEANS.'

The example represents the appropriate and most common reply to the question indicated.

We conclude from such findings that in a canonical SVO sentence the postverbal position is the default position for NSF in these languages: The canonical SVO sentence represents a categorical utterance with topic-comment structure.

If, on the other hand, NSF is additionally marked, we face a wide range of focus markings which are not restricted to the focus constituent, but may (also) be found in the out-of-focus part. Please note that we do not consider language specific restrictions concerning the general marking of focus in this paper.

\subsection{Morphological focus marking}

Morphological focus marking without syntactic changes compared to the canonical SVO order is prominent in Buli, Konni, Dagbani, Gurene, Konkomba, Byali, Ditammari (Gur), Guruntum, Bole (Chadic).

(2) Buli (Gur, Oti-Volta, Buli-Konni)

Q: What did the woman eat?

A: j̀ yòb kà túé.

3 sg eat FM beans

'She ate BEANS.'

The focus marker (FM) ká precedes the focused object (Schwarz 2004). 
(3) Ditammari (Gur, Oti-Volta, Eastern)

Q: What did the woman eat?
A: ò dī yātũ̀rà ǹyā.
3 sg eat beans FM
'She ate BEANS.'

The FM, here ìy $\bar{a}$ (gender agreement), follows the focused object (Reineke, to appear).

(4) Guruntum (West Chadic)

Q: What is he chewing?
A: Tí bà wúm á kwálíngálá.
3sg PROG chew FM colanut
'He is chewing COLANUT.'

The focus marker $a$ precedes the focus constituent (Hartmann \& Zimmermann 2006).

The languages in this group have grammaticalized morphological focus marking, while at the same time conforming to the generalization that the focus constituent is placed in the postverbal default position for NSF.

\subsection{Syntactic focus marking}

Syntactic focus marking implies reordering of the focus constituent relative to the rest of the clause. There are two sub-cases depending on whether there are additional changes in the outof-focus part. Apart from this distinction, the FM is obligatorily required in some of the languages, while it is just optional in others.

\subsubsection{Ex-situ strategy without additional out-of-focus marking}

(Aja, Fon, Lelemi, Foodo,...)

(5) Fon (Kwa, Gbe)

Q: What did the woman eat?
A: àyìkún (wè) nyònú ó dù.
beans (FM) woman DEF eat
'The woman ate BEANS.'

The focus constituent is placed in left-peripheral position, optionally followed by FM wè (cf. Ameka 1992, Höftmann 1993, Fiedler 1998, Lefebvre \& Brousseau 2002, Aboh 2004 for Fon and other Gbe languages). 


\subsubsection{Ex-situ strategy with additional out-of-focus marking}

(Ewe, Byali, Nateni, Yom, Buli, Konni, Dagbani, Akan, Konkomba, Efutu, Hausa, ...)

(6) Ditammari (Gur)

Q: What did the woman eat?
$\mathrm{A}$ : yātũ̀rà ǹyā ò $\mathrm{d} \overline{\mathrm{i}}$ mà. beans FM 3sg eat DEP
'The woman ate BEANS.'

The focus constituent is fronted to the left-peripheral position, followed by FM h̀y $\bar{a}$, and sentence-finally, morpheme mà is required in the out-of-focus part.

(7) Hausa (West Chadic)

Q: What is Kande cooking?
A: Kúifíi (nee) Kandé tá-kee dáfaawáa.
fish (PRT) Kande 3sg.f-prog.rel cooking
'Kande is cooking FISH.'

The focus constituent is fronted to the left-peripheral position, optionally followed by particle nee, the person-aspect-marker appears in special relative form (tá-kee) observed with fronting (Tuller 1986, Newman 2000, Hartmann \& Zimmermann, in press).

(8) Buli (Gur, Oti-Volta, Buli-Konni)

S: The woman ate black beans.

\section{A: (ká) tú-mòàntàyā tè wà yj̀b. \\ (FM) beans-red.DEF CNJ 3sg eat}

'She ate the RED beans. $\sim$ The RED beans is what she ate.

The focus-embedding NP (subphrasal focus) is in left-peripheral position of the sentence, optionally preceded by FM ká. The special out-of-focus features in this construction are: (i.) the obligatory use of conjunction (à)tè and (ii.) a special tone pattern on the verb.

These syntactically marked constructions are in many cases not simply triggered by whquestions, but need more /additional context, e.g. contrastiveness. Language-specific conditions also have to be considered.

\subsection{Prosodic focus marking}

(9) Tangale (West Chadic)

Q: What did Laku sell?
A: Lak wai-gó lánda
Laku sell-PERF dress
vs. Lak way-ug lánda. (all-new)
'Laku sold a DRESS.'
Laku sell-PERF dress
'LAKU SOLD A DRESS.' 
There is a phonological phrase $(\varphi)$-boundary before the focus constituent. The presence of the $\varphi$-boundary results in the blocking of tonal processes that would usually apply, such as vowel elision (VE), blocking the derivation of way-ug from wai-gó (Kenstowicz 1985, Tuller 1992, Hartmann \& Zimmermann 2004).

\subsection{Conclusions}

i. The languages under discussion show considerable variation concerning focus marking (even within one and the same language group).

ii. All languages exhibit in-situ focus (either unmarked or morphologically marked) in postverbal position. We consider this the default configuration for NSF (prototypical for new-information focus).

iii. Nearly all languages exhibit ex-situ focus constructions as well (not typical for newinformation focus).

iv. The Gur and Kwa focus systems differ typologically: different from the isolating Kwa languages, the agglutinating Gur languages tend to use more morphological marking.

\section{Asymmetries between subject focus and non-subject focus}

All languages under discussion exhibit asymmetries in the marking of subject focus (SF) and non-subject focus (NSF). We distinguish between two kinds of asymmetries:

i. Markedness Asymmetry

ii. Structural Asymmetry

\subsection{Markedness Asymmetry}

The conditions in (i) or (ii) hold for all languages under discussion:

i. NSF need not or cannot be syntactically marked

a. only unmarked (Chadic: Bole, Duwai, Ngizim, Bade, Ngamo (Schuh 1982))

b. optional NSF-marking (Chadic: Hausa; Kwa; Gur)

ii. SF must be marked (syntactically and/or morphologically).

(10) Hausa (West Chadic), optional absence of NSF-marking (cf. (7)):

Q: What is Kande cooking?

A: Kandé tá-naa dáfa kúifíi. unmarked NSF

Kande 3sg.f-prog cooking fish

'Kande is cooking (a) FISH.'

S: Kande is cooking meat.

A: Kúifíi (nee) Kandé tá-kee dáfaawáa. marked NSF

fish (PRT) Kande 3sg.f-prog.rel cooking

'Kande is cooking (a) FISH.' 
(11) Hausa (West Chadic), obligatory SF-marking:

Q: Who is cooking (the) fish?

marked SF
A: Kandé tá-kee dáfa kíifíi
Kande 3sg.f-prog.rel cooking fish
'KANDE is cooking (the) fish.'

The obligatory (vacuous) fronting of the focused subject is indicated by the obligatory relative morphology on the person-aspect-marker.

\subsection{Structural asymmetry}

The markedness asymmetry aside, the structural devices for marking SF and NSF (in sentence-peripheral position) may differ. Our language sample is heterogenuous with respect to number and form of the observed differences.

Grade 0: No structural differences between SF-marking and NSF-marking (Chadic: Guruntum, Tangale; Gur: Byali, Konkomba).

Grade 1: $\quad$ SF-marking and NSF-marking differ in only one structural aspect, most often with regard to the optionality of the FM (Kwa: Aja, Akan, Efutu, Ewe, Fon, Foodo; Gur: Gurene, Nateni, Yom; Chadic: Bole, Hausa)

(12) Fon (Kwa, Gbe)

Q: Who ate the beans?

$S F:$
A: nỳ̀nú ’́ wè dù àyìkún. woman DEF FM eat beans
obligatory FM wè

'THE WOMAN ate the beans.'

Q: What did the woman eat?

$N S F$ :
A: àyìkún (wè) nyònú ó dù.
fronting + optional FMwè
beans (FM) woman DEF eat
'The woman ate BEANS.'

The only difference consists in the optionality of the focus marker: it is obligatory in SF, which would otherwise constitute the canonical sentence typical for object focus.

(13) Bole (West Chadic)

Q: Who is planting the millet?

$S F:$
$\mathrm{A}$ : (An) jìi kàppà mòrdó yé Léngì. inversion $+P R T$ yé
(3sg) PROG planting millet PRT Lengi
'LENGI is planting the millet.' 
Q: What is Lengi planting?

$N S F$ :
A: Léngì à jìi kàppà (yé) mòrdó.
optional + PRT yé
Lengi AUX PROG planting (PRT) millet
'Lengi is planting MILLET.'

In NSF, ye is optionally inserted, whereas in SF, reordering occurs and the particle ye is obligatory.

Grade 2: SF-marking and NSF-marking differ in more than one structural aspect, or SF and NSF are marked in fundamentally different ways. (Gur: Buli, Dagbani, Ditammari, Gurene, Konni; Kwa: Lelemi)

(14) Buli (Gur, Oti-Volta, Buli-Konni) (cf. 8)

Q: Who ate the beans?
A: (ká) márỳ àlē ỳ̀bī.
$S F$ :
(FM) Mary $\mathrm{CNJ}_{1}$ eat
optional FM ká
'MARY ate them.'
$+\mathrm{CNJ}_{1}+$ tone $_{1}$

S: The woman ate black beans.

A: (ká) tú-mòàntàyā tè wà Đòb. NSF:

(FM) beans-red.DEF $\mathrm{CNJ}_{2} \quad 3 \mathrm{sg}$ eat optional FM $k a ́$

'She ate the RED beans. $\quad+\mathrm{CNJ}_{2}+$ tone $_{2}$

$\sim$ The RED beans is what she ate.'

Here, the difference lies not in the optionality of the preposed focus marker $(k a)$, but in the choice of the conjunction ( $L E$ with SF, TE with NSF) and in the verb tone (here: rising tone at sentence-final verb in SF, L tone in NSF).

(15) Lelemi (Kwa, Na-Togo)

Q: Are the boys eating oranges?

A: ’̀nàabì ùmwì pé mò-dí kùtú. $\quad$ pF:

boy one only REL.IPF-eat orange relative TAM

'Only ONE boy is eating an orange.'

S: The boy is eating a banana.

A: kùtú nà ònàabì ómò ̀̀̄-dì. $\quad N S F$ :

orange CNJ boy DEM 3sg.IPF-eat conjunction nà

'The boy is eating an ORANGE.'

These constructions differ in that SF constructions require the relative verb form, NSF the common, so-called "simple" verb form, following the conjunction nà. 


\subsection{Conclusion}

While the markedness asymmetry is a general feature of our language sample (with possibly cross-linguistic implications), the structural asymmetry has language-specific traits. The table gives an overview of the realization of SF/NSF in the languages discussed with special regard to the respective grade of asymmetry.

Tab.1: Overview of SF/NSF realization in the languages illustrated

\begin{tabular}{|c|c|c|c|c|}
\hline \multirow[t]{2}{*}{ 1. Language } & \multicolumn{2}{|l|}{ 2. NSF (term, DP) } & \multirow[t]{2}{*}{ 3. SF } & \multirow{2}{*}{$\begin{array}{l}\text { 4. Structural } \\
\text { Asymmetry }\end{array}$} \\
\hline & 2a. NSF in situ & 2b. NSF ex situ & & \\
\hline $\begin{array}{l}\text { Byali } \\
\text { (Gur) }\end{array}$ & FM ye & $\begin{array}{l}\text { FM ye + out-of- } \\
\text { focus relative form }\end{array}$ & $\begin{array}{l}\text { FM ye + out-of- } \\
\text { focus relative form }\end{array}$ & 0 \\
\hline $\begin{array}{l}\text { Tangale } \\
\text { (Chadic) }\end{array}$ & phrase boundary & \multirow[t]{3}{*}{ not applicable } & $\begin{array}{l}\text { subject inversion }+ \\
\text { phrase boundary }\end{array}$ & 0 \\
\hline $\begin{array}{l}\text { Guruntum } \\
\text { (Chadic) }\end{array}$ & FMá & & FM á & 0 \\
\hline $\begin{array}{l}\text { Bole } \\
\text { (Chadic) }\end{array}$ & optional PRT yé & & $\begin{array}{l}\text { subject inversion }+ \\
\text { PRT yé }\end{array}$ & 1 \\
\hline $\begin{array}{l}\text { Hausa } \\
\text { (Chadic) }\end{array}$ & \multirow[t]{3}{*}{ no marking } & $\begin{array}{l}\text { optional PRT nee/cee } \\
+ \text { relative TAM }\end{array}$ & $\begin{array}{l}\text { optional PRT nee } \\
\text { /cee + relative TAM }\end{array}$ & 1 \\
\hline $\begin{array}{l}\text { Fon } \\
\text { (Kwa) }\end{array}$ & & optional FM wè & $\mathrm{FM} w \grave{\varepsilon}$ & 1 \\
\hline $\begin{array}{l}\text { Lelemi } \\
\text { (Kwa) }\end{array}$ & & optional CNJ nà & relative TAM & 2 \\
\hline $\begin{array}{l}\text { Buli } \\
\text { (Gur) }\end{array}$ & FM $k a ́$ & $\begin{array}{l}\text { optional FM ká }+ \\
\text { out-of-focus } \mathrm{CNJ}_{2}+ \\
\text { tone }_{2}\end{array}$ & 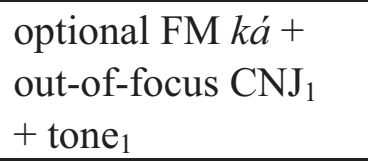 & 2 \\
\hline $\begin{array}{l}\text { Ditammari } \\
\text { (Gur) }\end{array}$ & $\mathrm{FM} N-C L_{1}$ & $\begin{array}{l}\text { FM } N-C L_{1}+\text { out-of- } \\
\text { focus PRT mà }\end{array}$ & $\mathrm{FM} C L_{2}$ & 2 \\
\hline $\begin{array}{l}\text { Konni } \\
\text { (Gur) }\end{array}$ & $\mathrm{FM}-w \dot{A}$ & $\begin{array}{l}\text { out-of-focus PRT } d i \\
\text { resp. special pronoun } \\
+ \text { tone }\end{array}$ & $\begin{array}{l}\text { out-of-focus verb } \\
\text { suffix }-n \grave{A}+\text { tone }\end{array}$ & 2 \\
\hline
\end{tabular}

\section{On the special status of focused subjects}

Question: Is the special status of focused subjects due to syntactic/semantic factors or to information-structural factors?

Hypothesis: The special status of focused subjects is conditioned by information structure: Subjects in canonical sentence-initial position are prototypically interpreted as topics (i.e. they are anti-focal) in the languages discussed. Therefore, if a subject is in focus, this conflicts with its primary topical status and results in a non-canonical construction. 
In our sample, there are two prominent strategies to deal with this conflict:

i. Predicate incorporation

$\rightarrow$ section 3.1

ii. Subject inversion

$\rightarrow$ section 3.2

\subsection{Predicate incorporation}

Empirical Generalization I: (for many Gur languages)

i. The grammar of these languages requires that focus in the default focus position (postverbal in canonical sentence) is morphologically marked.

$\rightarrow$ grammatical focus system

ii. Subjects are restricted to preverbal position and are thus excluded from the default focus position.

$\rightarrow$ In order to avoid their interpretation as topic, the so-called thetic construction, i.e. an utterance without topic, constitutes the basis for the subject focus construction.

The assumption that the focalization of subjects occurs in a topicless, thetic construction is strongly supported by the following three observations:

1. Subject-sentence-focus isomorphism: The same construction is used for subject focus and for sentence focus, because both are typically without topic.

(16) Konni (Gur, Oti-Volta, Buli-Konni)

Q: Who hit Peter?
A: Márỳ nígí-nà-wà.
Subject Focus:
Mary hit-NA-3sg
special verb tone + suffix $-n \grave{A}$

'MARY hit him.'

Q: What happened?
A: Márỳ nígí-nà Pétèr.
Mary hit-NA Peter
Sentence Focus:
special verb tone + suffix $-n \grave{A}$

'MARY HIT PETER.'

2. Introduction of major discourse referents: The "subject focus construction" is typically found text-initially, where discourse topics are rare / absent. In Byali, the structural features which are also present in relative clauses consist of a predicate-initial nasal and a verb-final agreement marker.

(17) Byali (Gur, Oti-Volta, Eastern)

hīrāū ń-yī bō-ū bā tóú pwōbò nùm.

man N-PAST be-CL CONS have women five

'There was a man, he had five women.'

3. Structural incompatibility: The "subject focus construction" is incompatible with certain linguistic expressions, for example with expletive pronominal forms that are typically used for topical entities. 
(18) Konni (Gur, Oti-Volta, Buli-Konni)

Q: What happened?

A: bà mì̀rì-wá bùànyààlín. *bà mírrí-nà bùànyààlín.

3 pl give.birth-FM baby

'A CHILD HAS BEEN BORN.'

The all-new sentence-focus is based on a structurally categorical utterance:

'They GAVE BIRTH TO A CHILD.'.

Conclusions:

i. Similar findings concerning the distribution and function of thetic utterances are reported for European and other languages (cf. Sasse 1987, 1995).

ii. The +/-topical status of the subject influences the choice of the focus construction in these languages.

$\rightarrow$ If the subject represents the unmarked topic, focus remains within the comment.

$\rightarrow$ If focus is not restricted to the comment (subject focus, sentence focus), a topicless (thetic) construction is used.

iii. Thetic utterances come with their own construction type. Typically, the predicate is manipulated: it forms a relative attribute to the subject or it shows incorporation features.

\subsection{Subject inversion}

A restricted number of (areally related) West Chadic SVO languages mark narrow subject focus by means of subject inversion (Bole, Tangale, Bade, Ngizim, Duwai): The focused subject does not occur in its canonical preverbal position, but is placed in post-verbal position:

(19) Bole (West Chadic) (cf. 13)

Q: Who is planting the millet?

$\mathrm{A}$ : (An) jìi kàppà mòrớ yé Léngì. (one) PROG planting millet PRT Lengi 'LENGI is planting the millet.'

(20) Tangale (West Chadic)

way-ug land-í ) nón ?

sell-perf dress-the who

'WHO sold the dress?'

Empirical Generalization II: (for a subset of West Chadic languages)

Whenever a subject is not to be interpreted as topic, but as focus, it must occur in the prototypical focus position, i.e. in a postverbal position towards the end of the clause. 
$\rightarrow$ A similar requirement has been observed for some Romance languages, including Italian (Samek-Lodovici 2005) and Spanish (Zubizaretta 1998), and for Bantu (Demuth \& Mmusi 1997).

$\rightarrow \quad$ There seems to be a strong requirement to place all focus constituents (not only nonsubjects) in the prototypical (in some sense prominent) focus position: Focused subjects need not only be marked as non-topics, but they must also be marked as foci.

Consequences:

i. Focus is of direct grammatical relevance for the languages of this group.

ii. Structural analogy between SF and NSF: V ... X $\mathrm{XOC}_{\mathrm{FOC}} \ldots$

iii. Sentence focus in these languages cannot be expressed by means of inversion, as it is impossible for the entire focused clause to occur in the prototypical postverbal focus position.

$\rightarrow$ No subject and sentence focus isomorphism ( $\neq$ Gur languages). Instead, sentence focus is realized with canonical SVO-order with no other markers.

$\rightarrow$ Isomorphism between (unmarked) NSF and sentence focus (= many accent languages including German, English, ...)

\section{Conclusion}

The following points emerge from the discussion of (term) focus marking in Kwa, Gur and (West) Chadic:

i. Focus can be marked in a variety of ways in these West African tone languages.

ii. All languages in the sample exhibit a clear subject vs. non-subject asymmetry when it comes to focus realizations: subject focus must be encoded in a special way.

iii. The special status of focused subjects in Kwa, Gur, and (West) Chadic follows from the cross-linguistically well attested fact that the subject in sentence-initial position is assigned a default topic interpretation in categorical utterances.

iv. If there is no prototypical match between subject and topic however, for instance in a topicless (thetic) utterance, the languages of our sample show parametric variation:

- Some languages mark the predicate as subordinated, partially as relative attribute. This encoding is prerequisite for any additional focus marking on the subject. $\rightarrow$ predicate incorporation (many Gur)

- Some languages don't reflect the non-topical status of the subject and/or just place the focus marker on the non-topical subject in the prototypical sentence-initial topic position.

$\rightarrow$ structural ignorance (many Kwa)

- Some languages mark non-topical, but focused subjects by placing them in the prototypical postverbal focus position.

$\rightarrow$ subject inversion (West Chadic)

www.sfb632.uni-potsdam.de www2.hu-berlin.de/gur_und_kwa_fokus 


\section{References}

Aboh, E. O. (2004). The morphosyntax of complement-head sequences. Clause structure and word order patterns in Kwa: Oxford studies in comparative syntax. Oxford, New York: Oxford University Press.

Ameka, F. (1992). Focus constructions in Ewe und Akan: A comparative perspective. In Proceedings of the Kwa comparative syntax workshop, eds. Chris Collins and Victor Manfredi, 1-25. Cambridge.

Chafe, W. (1976). Givenness, contrastiveness, definiteness, subjects and topics. In Subject and Topic, ed. Charles N. Li, 22-55. New York: Academic Press.

Demuth, K. \& Mmusi, S. (1997). Presentational focus and thematic structure in comparative Bantu, in: Journal of African Languages and Linguistics 18, pp. 1-19.

Dik, S. 1997. The theory of functional grammar I. The Structure of the Clause.vol. 1: Functional Grammar Series 20. Berlin: Mouton de Gruyter.

Fiedler, I. (1998). Fokus im Aja. In Afrikanische Sprachen im Brennpunkt der Forschung. Linguistische Beiträge zum 12. Afrikanistentag, Berlin, 3.-6. Oktober 1996, eds. I. Fiedler, C. Griefenow-Mewis and B. Reineke, 75-89. Köln: Köppe.

-- $\quad$ (to appear). Focus Expressions in Yom, Cahiers Voltaïque / Gur Papers

Fiedler, I., Reineke, B. \& A. Schwarz. (2005). Let's focus it: Fokus in Gur- und Kwasprachen. In: Heusing, G. (ed.). Sprach- und literaturwissenschaftliche Beiträge zum 16. Afrikanistentag (Beiträge zur Afrikanistik, Bd. 15). Hamburg: LIT Verlag.

Fiedler, I.\& A. Schwarz. (2005). Out-of-focus Encoding in Gur and Kwa. In: Ishihara, S., M. Schmitz and A. Schwarz (eds.): Interdisciplinary Studies on Information Structure 03, 111-142. Potsdam: Potsdam University.

-- $\quad$ (to appear). Focus or Narrative Construction? In: Aboh, E., K. Hartmann \& M. Zimmermann (eds.), Focus Strategies: Evidence from African Languages, Berlin: de Gruyter.

Hartmann, K. \& M. Zimmermann (2004) Focus Strategies in Chadic - The Case of Tangale Revisited. In: S. Ishihara, M. Schmitz and A. Schwarz (eds) Interdisciplinary Studies on Information Structure. Working Papers of the SFB 632.

-- $\quad$ (2006). Focus Marking in Guruntum, Ms, Humboldt University Berlin (submitted to Language)

-- $\quad$ (in press) In Place - Out of Place: Focus in Hausa. To appear in: K. Schwabe \& S. Winkler (eds.) Information Structure and the Architecture of Grammar: A Typological Perspective. Amsterdam: John Benjamins.

Höftmann, H. (1993). Grammatik des Fon. Leipzig u.a.: Langenscheidt.

Jackendoff, R. (1972). Semantic Interpretation in Generative Grammar. Cambridge, MA: MIT Press.

Kenstowicz, M. (1985). The Phonology and Syntax of WH-Expressions in Tangale. In Studies in the Linguistic Sciences 15, 79-91.

Lefebvre, C. , and Brousseau, A. (2002). A Grammar of Fongbe. Berlin, New York: Mouton de Gruyter.

Li, C. N., and Thompson, S. A. (1976). Subject and Topic: A New Typology of Language. In Subject and topic, ed. C. N. Li, 457-489. New York/San Francisco/London: Academic Press.

Newman, P. (2000). The Hausa Language. New Haven \& London: Yale University Press.

Reineke, B. (to appear). Identificational Operation as Focus Strategy in Byali. In: Aboh, E., K. Hartmann \& M. Zimmermann (eds.), Focus Strategies: Evidence from African Languages, Berlin: de Gruyter.

-- $\quad$ (to appear). Focus et topique dans les langues gur, Cahiers Voltaïque / Gur Papers.

Samek-Lodovici, V. (2005). Prosody-Syntax Interaction in the Expression of Focus. Natural Language and Linguistic Theory 23. 687-755.

Sasse, H.-J. (1987). The thetic/categorial distinction revisited. Linguistics 25:511-580.

-- (1995). 'Theticity' and VS order: A case study. In Verb-subject order and theticity in European languages (Sprachtypologie und Universalienforschung, 48: 1/2), eds. Y. Matras and H.-J. Sasse, 3-31. Berlin.

Schuh, R. (1982). Questioned and focused subjects and objects in Bade/Ngizim. In The Chad Languages in the Hamitosemitic-Negritic Border Area, H. Jungraithmayr (ed.), 160-174. Berlin: Reimer

Schwarz, Anne. (2004). Aspekte der Morphosyntax und Tonologie im Buli. Mit Schwerpunkt auf dem Buli von Wiaga. Dissertation, Humboldt-Universität zu Berlin.

-- (to appear). Predication Focus and 'Affirmative Markers' in Gur. In Information Structure in African Languages: Typological Studies in Language (TSL). eds. I. Fiedler, T. Güldemann \& A. Schwarz. Amsterdam, Philadelphia: John Benjamins.

Tuller, L. (1986). Bijective Relations in Universal Grammar and the Syntax of Hausa. PhD Dissertation, UCLA, Los Angeles.

-- $\quad$ (1992). The Syntax of Postverbal Focus Constructions in Chadic. Natural Language and Linguistic Theory 10: 303-334.

Zubizarreta, M. L. (1998). Prosody, Focus and Word Order. Cambridge, Mass.: MIT Press. 